\title{
Quality Changes in Different Cultivars of Sweet Potato During Deep-Fat Frying
}

\author{
Amaka Odenigbo ${ }^{1 *}$, Jamshid Rahimi ${ }^{1}$, Michael Ngadi', David Wees ${ }^{2}$, Arif Mustafa ${ }^{3}$ and Philippe Seguin ${ }^{2}$
}

${ }^{1}$ Department of Bioresource Engineering, McGill University, Canada

${ }^{2}$ Department of Plant Science, Mc Gill University, Canada

${ }^{3}$ Department of Animal Science, McGill University, Canada

\begin{abstract}
The goal of this study was to evaluate quality changes during deep fat frying of five cultivars of sweet potato (Ipomoea batatas L.) namely, 'Ginseng Red', 'Beauregard', 'White Travis', 'Georgia Jet clone \#2010' and 'Georgia Jet'. The cultivars were grown in Sainte-Anne-de-Bellevue, QC, Canada, harvested at maturity, and brought to the laboratory for analysis. Samples were peeled, sliced into cylindrical shape and deep fried in canola oil at the temperature of $180^{\circ} \mathrm{C}$ for different times up to $5 \mathrm{~min}$. Oil uptake, moisture loss, colour and texture parameters were measured. Oil uptake and moisture loss during frying followed the traditional 1st order kinetics profile for all the cultivars. A significant $(P<0.05)$ variation was observed in the rate of quality changes such as moisture loss and oil uptake in different cultivars after frying. 'Ginseng Red' was identified as a suitable cultivar for French fries production because of its lowest oil saturation, good colour and textural properties development during frying.
\end{abstract}

Keywords: Sweet potato; Ipomoea batatas; Deep frying; Oil uptake; Moisture loss; Colour; Texture

\section{Introduction}

Sweet potato (Ipomoea batatas L.) is an important food crop around the world [1]. Orange-fleshed cultivars have been recognized as healthy foods because of their significant content of phytonutrients, such as $\beta$-carotene, phenolic acids, anthocyanin, and dietary fibre [24]. The crop is widely cooked by deep frying and consumed in forms of French fries and chips [5]. The frying process results in unique flavor, colour and texture attributes which are the main drivers of consumer acceptability of the products [6,7]. However, consumers are increasingly health conscious and trends are moving toward foods with low oil content [8]. Consumer preference for low-fat food products has been the driving force for the food industry to produce good quality fried potatoes with reduced oil uptake [9]. Too much oil content in a fried product endows it with an oily taste while too little oil content deprives it of the typical appealing taste and odour of the fried product. Oil uptake in fried potato products has generally been related to the amount of moisture, starch and dry matter content of the raw potato as well as temperature of the frying oil $[10,11]$. Cultivar choice had also been found to have significant influence on oil uptake in French fries; the cellular structures of different cultivars affecting moisture loss and subsequent oil uptake in the finished product [12]. Several studies have shown that higher initial moisture content in the food material resulted in increased fat uptake in the finished products. This is because in deep frying, high temperatures (between 160 and $180^{\circ} \mathrm{C}$ ) cause water to evaporate from the food towards the surrounding oil, while the food absorbs oil to replace part of the evaporated water $[11,13]$.

Some models that describe the characteristics of moisture loss and fat uptake, as well as the relationship between moisture loss and fat uptake in deep fried food products have been developed [1416]. Textural attributes of fried potatoes include firmness, hardness, and elastic modulus. Firmness has been commonly used as a texture parameter since it is related to the sense of chewing [17]. Changes in texture of sweet potato French fries are influenced by changes in the cellular and sub cellular structure of the products. These changes have been attributed to starch gelatinization in the product during frying
[18]. Several studies have documented changes in colour, texture and oil uptake of sweet potato products $[12,16,19,20]$.

Despite a growth in sweet potato consumption in Canada, most sweet potatoes currently consumed are imported from the USA; local production is currently limited because of the short growing season. There is, however, a strong interest among local agricultural producers to diversify their production, and sweet potato is one crop with local potential and for which demand is increasing. There are dozens of cultivars of sweet potatoes available that vary in their flesh colour, sugar content and \% dry matter [21]. Currently 'Beauregard', an orange-fleshed variety, is one of the widely grown in the USA as well as southern Ontario, Canada. 'Georgia Jet' has been recommended for production in regions with short, cool growing seasons [22]. The goal of this study was to determine differences among cultivars ['Ginseng Red', 'Beauregard', 'White Travis', 'Georgia Jet clone \#2010', and 'Georgia Jet'] for moisture loss, oil uptake, texture, and colour characteristics of their French fries products and to study the kinetics of their changes. This ultimately will provide useful information that could led to the identification of cultivars most suited for French fries production, and thus most suitable for the food industry. Such information will be valuable for eastern Canadian agricultural producers in identifying the most desirable sweet potato cultivars to be grown locally.

\section{Materials and Methods}

\section{Samples}

Five different cultivars of sweet potato were used for this study:

*Corresponding author: Amaka Odenigbo, Department of Bioresource Engineering, McGill University, 21111 Lakeshore Road, Sainte-Anne-de-Bellevue, QC H9X 3V9, Canada, E-mail: amakajesu1@yahoo.com

Received April 02, 2012; Accepted May 08, 2012; Published May 11, 2012

Citation: Odenigbo A, Rahimi J, Ngadi M, Wees D, Mustafa A, et al. (2012) Quality Changes in Different Cultivars of Sweet Potato During Deep-Fat Frying. J Food Process Technol 3:156. doi:10.4172/2157-7110.1000156

Copyright: (c) 2012 Odenigbo A, et al. This is an open-access article distributed under the terms of the Creative Commons Attribution License, which permits unrestricted use, distribution, and reproduction in any medium, provided the original author and source are credited. 
Ginseng Red (GR) which is an heirloom variety with pale orange flesh, Beauregard (B), a widely grown, high-yielding orange-fleshed cultivar released in 1987, White Travis (WT), a white-fleshed mutant of the original 'Travis' which was released in 1980, Georgia Jet (GJ), a high yielding cultivar suggested for cool climates, and Georgia Jet clone \#2010 (GJ \#2010), a clone selected from a white-fleshed mutant of 'Georgia Jet' in 2010. All cultivars were grown in a loam soil at the Horticultural Research Centre of Macdonald Campus of McGill University located in Sainte-Anne-de-Bellevue, QC, Canada ( $45^{\circ} 24^{\prime} \mathrm{N}$, $73^{\circ} 57^{\prime} \mathrm{W}$ ). After installing a black plastic mulch to heat the soil, rooted cuttings were planted on June 15, 2011, harvested on October 5, 2011 with a soil temperature of $10^{\circ} \mathrm{C}$ at harvesting. Although the suggested growing season differs slightly (Beauregard and White Travis; midseason maturity while Ginseng Red, Georgia Jet and Georgia Jet clone \#2010; early season maturity) the sweet potato will in fact keep on growing until it is either harvested or the weather gets too cold with soil temperatures of $<10^{\circ} \mathrm{C}[23]$.

After harvest, the tubers were manually peeled with a hand peeler and immediately cut into discs using a cylindrical borer and a slicer. The dimensions of the discs were $5 \mathrm{~mm}$ thickness and $22 \mathrm{~mm}$ diameter.

\section{Frying}

A kitchen deep fat fryer (T-FAL, Model 6197, Scarborough, ON, Canada) was used for frying. The fryer was filled with $1.5 \mathrm{~L}$ of canola oil and temperature was measured using a K-type thermocouple (HHM16, OMEGA Engineering Inc., Stamford, CT, USA). The fresh oil was preheated and maintained at $180 \pm 2{ }^{\circ} \mathrm{C}$ for frying all the samples. All samples were fried for $1,2,3,4$, and $5 \mathrm{~min}$, and then drained by shaking the fryer basket and blotting fried product with tissue paper to remove excess oil on the surface. To minimize the variation of oil properties due to degradation during frying, each batch of oil was used for only cumulation of $30 \mathrm{~min}$ before it was replaced with a fresh batch of oil. All experiments were performed in triplicate [24].

\section{Sample analysis}

Fried sweet potatoes were weighed, and then dried at $105^{\circ} \mathrm{C}$ to a constant weight in a forced air convection oven (Isotemp 700, Fisher Scientific, Pittsburgh, PA, USA). Moisture content was determined by gravimetric method [25]. AOAC standard procedure and Soxhlet method were used for fat extraction and analysis [26]. The dried samples were ground by coffee grinder, and then approximately $5 \mathrm{~g}$ of each was weighed for fat extraction. The fat was extracted using petroleum ether in a Soxhlet extractor (SER148, Velp Scientifica, Usmate, Italy). The oil content was obtained on dry weight basis for each sample as the ratio of mass of oil extracted to mass of dried samples. Color characteristics (based on L, a and b parameters) of fried sweet potatoes were obtained by using a Konica Minolta colorimeter (Model No: CR-300, Konica Minolta, Sensing, Inc. Osaka, Japan). The instrument was calibrated before reading measurements using a white ceramic plate. Texture was evaluated by a compression test on an Instron Universal Testing Machine (Model 4502, Canton, MA, USA). Fried sweet potato samples were compressed to a depth of $2.5 \mathrm{~mm}$ (from the original $5 \mathrm{~mm}$ ) using a cylindrical $5 \mathrm{~mm}$ diameter probe at $5 \mathrm{~N}$ load and a cross head speed of $5 \mathrm{~mm} / \mathrm{min}$. The temperature and humidity during tests were $23^{\circ} \mathrm{C}$ and $50 \%$, respectively. Load-displacement curves were obtained. Maximum force $(\mathrm{N})$ and slope of the linear section of the load-displacement curve were recorded as hardness and elastic modulus, respectively.
Compression test was repeated on nine sweet potato discs and mean values were used as indicators of the textural properties of fresh and fried samples [7].

\section{Statistical analysis}

A $5 \times 5$ factorial ( 5 cultivars $x 5$ frying times) experimental design was applied to conduct the experiments. The SAS System software (Version 9.2, SAS Institute, Inc., 1999, Cary, NC, USA) was used for statistical analysis. Duncan's multiple range test (DMRT) was used to estimate significant differences among the means at a $5 \%$ probability level. All analyses were conducted in triplicate.

\section{Kinetics model}

A first order kinetics was used to describe oil uptake and moisture loss during deep-fat frying [15]. Recognizing that there is a saturation oil content beyond which minimal oil is absorbed into the product during frying, the following rate equation was used.

$$
\frac{d O}{d t}=-K_{o u}\left(O-O_{e}\right)
$$

where $\mathrm{O}$ is oil uptake in the sample, $\mathrm{O}_{\mathrm{e}}$ is equilibrium oil content, $\mathrm{K}_{\mathrm{ou}}$ is oil uptake rate constant and $t$ is frying time. Integrating, the equation can be adjusted and expressed in the form of oil uptake as follows:

$$
O_{u}=O_{u s}\left(1-e^{-K_{o u} t}\right)
$$

where $\mathrm{O}_{\mathrm{u}}$ is oil uptake (defined as the difference between oil content at a given time and the initial oil content) and $\mathrm{O}_{\text {us }}$ is saturation oil content (i.e., the difference between equilibrium oil content and the initial oil content).

Considering the high frying temperature, equilibrium moisture content was assumed to be zero that means moisture is completely evaporated. Indeed, a real equilibrium does not exist in process of deep fat frying; however, the system behaves as if there is equilibrium mainly due to restriction of moisture and oil transfers, which is caused by the physical changes in the product during frying. Thus the kinetics of moisture loss was described using the model [14]:

$$
\frac{d M}{d t}=-K_{m l} M
$$

From which Equation (4) was obtained.

$$
M^{*}=e^{-K_{m l} t}
$$

$\mathrm{M}^{*}$ is moisture ratio (calculated as the ratio of moisture at a given time and initial moisture) and $\mathrm{K}_{\mathrm{ml}}$ is the moisture loss rate constant.

The kinetic parameters were obtained using nonlinear linear regression in MATLAB (Version 7.6.0.324 R2008a, The Mathworks, Inc., Natick, MA, USA).

\section{Results and Discussion}

The initial moisture content of the sweet potato samples ranged from $64.76 \pm 1.64-78.42 \pm 1.19 \%$ wet basis (Table 1). Cultivars WT and GR had significantly lower initial moisture content $(64.76 \pm 1.64 \%$ and $67.05 \pm 1.50 \%$ respectively) compared to the other cultivars $(\mathrm{P}<0.05)$. The mean oil uptakes among cultivars were in the range of $4.80 \pm$ $0.17-9.61 \pm 0.91 \%$ dry matter basis. These values are within the range reported in the literature for potato French fries [18]. Moisture changes during frying (Figure 1) showed the typical progressive decrease with frying time $[16,18,27]$. The kinetics results (Table 2) showed that all the 


\begin{tabular}{|c|c|c|c|c|c|c|c|}
\hline \multirow{2}{*}{ Cultivars } & \multirow{2}{*}{$\begin{array}{c}\text { Oil uptake (\% dry } \\
\text { basis) }\end{array}$} & \multirow{2}{*}{$\begin{array}{c}\text { Initial moisture content (\% } \\
\text { wet basis) }\end{array}$} & \multicolumn{3}{|l|}{ Colour } & \multicolumn{2}{|l|}{ Texture } \\
\hline & & & $\mathbf{L}$ & a & b & $E(\mathrm{~N} / \mathrm{mm})$ & $F(N)$ \\
\hline GJ \#2010 & $9.61 \pm 0.91^{\mathrm{a}}$ & $77.39 \pm 1.18^{a}$ & $62.98 \pm 3.43^{b}$ & $0.20 \pm 4.42^{\mathrm{d}}$ & $33.62 \pm 7.14^{c}$ & $2.15 \pm 1.44^{d}$ & $2.43 \pm 1.62^{b}$ \\
\hline WT & $8.55 \pm 0.32^{b}$ & $64.76 \pm 1.64^{b}$ & $71.21 \pm 3.21^{\mathrm{a}}$ & $1.10 \pm 5.76^{c}$ & $33.57 \pm 8.49^{c}$ & $3.40 \pm 1.30^{\mathrm{b}}$ & $3.97 \pm 0.85^{\mathrm{a}}$ \\
\hline $\begin{array}{l}\text { GJ } \\
\text { GR } \\
B\end{array}$ & $\begin{array}{l}8.78 \pm 0.56^{\text {ba }} \\
4.80 \pm 0.17^{c} \\
9.14 \pm 0.50^{\text {ba }}\end{array}$ & $\begin{array}{l}77.03 \pm 1.09^{a} \\
67.05 \pm 1.50^{b} \\
78.42 \pm 1.19^{a}\end{array}$ & $\begin{array}{l}63.46 \pm 4.23^{b} \\
60.40 \pm 2.68^{c} \\
57.15 \pm 2.75^{d}\end{array}$ & $\begin{array}{l}0.22 \pm 4.32^{d} \\
9.98 \pm 3.94^{b} \\
20.57 \pm 4.18^{a}\end{array}$ & $\begin{array}{l}34.73 \pm 5.15^{\mathrm{c}} \\
44.11 \pm 5.92^{\mathrm{b}} \\
47.71 \pm 2.96^{\mathrm{a}}\end{array}$ & $\begin{array}{l}2.17 \pm 0.97^{d} \\
4.16 \pm 1.58^{a} \\
2.68 \pm 0.94^{c}\end{array}$ & $\begin{array}{l}2.08 \pm 0.51^{b} \\
3.97 \pm 1.17^{a} \\
2.38 \pm 0.50^{b}\end{array}$ \\
\hline
\end{tabular}

Mean values followed by the same letters within a column are not significantly different $(P>0.05)$.

$L=$ lightness; $a=$ redness; $b=$ yellowness; $E=$ elastic modulus; $F=$ Maximum force

GJ \#2010= 'Georgia Jet clone \#2010'; WT='White Travis'; GJ='Georgia Jet'; GR= 'Ginseng Red'; B='Beauregard'

Table 1: Mean values for oil uptake, moisture loss, texture and colours of the different sweet potato cultivars after deep fat- frying

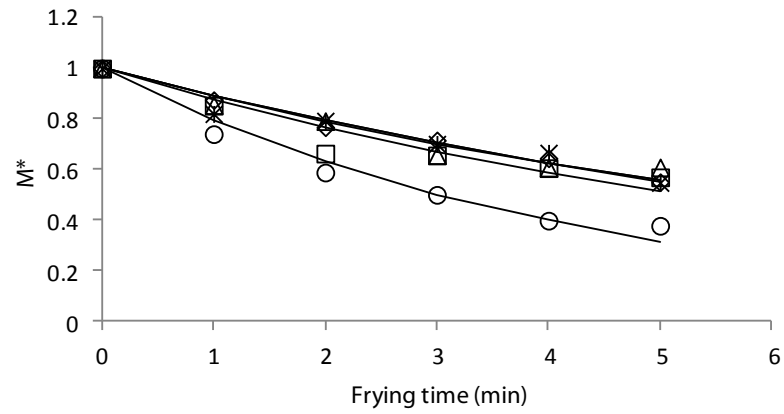

$\diamond \mathrm{GJ} \# 2010 \square \mathrm{GR} \Delta \mathrm{B}$ OWT $* \mathrm{GJ}$

Continuous line: predicted values

GJ \#2010= 'Georgia Jet clone \#2010'; WT='White Travis'; GJ='Georgia Jet'; $\mathrm{GR}=$ 'Ginseng Red'; B='Beauregard'

Figure 1: Moisture content during frying to initial moisture content ratio $\left(\mathrm{M}^{*}\right)$ of different sweet potato cultivars.

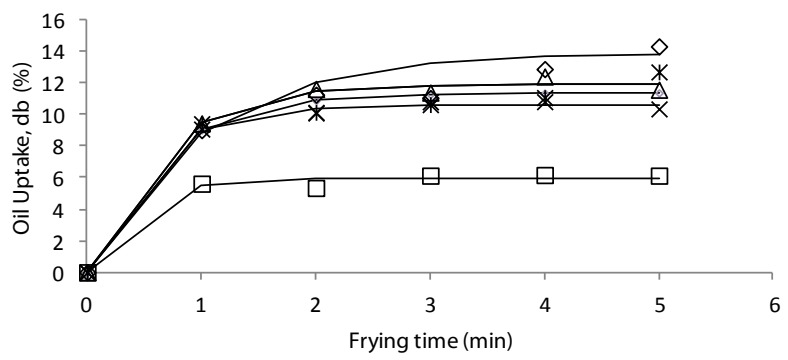

$\diamond \mathrm{GJ} \# 2010 \square \mathrm{GR} \Delta \mathrm{B} \times \mathrm{WT} * \mathrm{GJ}$

Continuous line: predicted values

GJ \#2010= 'Georgia Jet clone \#2010'; WT='White Travis'; GJ='Georgia Jet'; $\mathrm{GR}=$ 'Ginseng Red'; B='Beauregard'

Figure 2: Oil uptake by different sweet potato cultivars during deep frying

cultivars had similar moisture rate constant except cultivar WT that had very high moisture rate constant $\left(0.22 \pm 0.02^{-1}\right)$. There was more spread among cultivars for values of oil uptake rate constants (ranging from $1.01 \pm 0.15$ to $2.61 \pm 0.45 \mathrm{~min}^{-1}$ ) than for the values of moisture loss rate constants (Table 2). Basuny et al. [11] observed similar wider spread in oil uptake ( 38.43 to $50.23 \%$ ) than in moisture loss $(0.23$ to $0.40 \%$ ) among different potato cultivars. This study demonstrated that cultivars (B, GJ \#2010 and GJ) had high initial moisture content, low moisture loss rate and consequent high oil absorption during frying. Oil uptake rate was highest in cultivar GR $\left(2.61 \pm 0.45^{-1}\right)$ and lowest in GJ \#2010 $\left(1.01 \pm 0.15^{-1}\right)$. It is interesting to note that despite the highest rate of oil uptake in cultivar GR, its saturation oil content was lowest resulting in lower final oil content in product. Normally, oil absorption rate correlates with moisture loss for a given individual product $[15,16,28]$. It would have thus been expected that cultivar WT rather than GR would have had the highest rate of oil uptake. The result of this study illustrates that different products could follow different moisture loss and oil uptake kinetics (Figure 2). The differences could be attributed to the physicochemical properties, microstructure and how moisture is held in the different sweet potato cultivars used in this study. O'Connor et al. [12] reported that the effect of cultivar dominates oil uptake during frying. Their study attributed oil uptake in the French fries to the different cellular structure of the potato varieties.

Changes in maximum forces for the fried samples are shown in Figure 3. Maximum force for the cultivars tended to decrease with increasing frying time. However, a slight increase was observed at longer frying times (from $4-5 \mathrm{~min}$ ). This trend is similar to a previous study on potato [29]. The initial tissue softening is attributed to lamella media solubilization and gelatinization while hardening at longer time is due to crust development [15]. Cultivar GR had significantly higher

\begin{tabular}{|c|c|c|c|}
\hline Cultivars & $\mathbf{O}_{\text {us }}$ (\%dry basis) & $\mathbf{K}_{\text {ou }}\left(\mathbf{m i n}^{-1}\right)$ & $\mathbf{K}_{\text {ml }}\left(\mathbf{m i n}^{-1}\right)$ \\
\hline GJ \#2010 & $13.19 \pm 1.05$ & $1.01 \pm 0.15$ & $0.11 \pm 0.02$ \\
\hline WT & $10.63 \pm 1.01$ & $1.90 \pm 0.14$ & $0.22 \pm 0.02$ \\
\hline GJ & $11.40 \pm 0.95$ & $1.58 \pm 0.40$ & $0.11 \pm 0.01$ \\
\hline GR & $5.98 \pm 0.65$ & $2.61 \pm 0.45$ & $0.12 \pm 0.01$ \\
\hline B & $11.92 \pm 1.12$ & $1.60 \pm 0.16$ & $0.12 \pm 0.01$ \\
\hline
\end{tabular}

$\mathbf{O}_{\mathrm{us}}=$ Saturated oil uptake; $\mathbf{K}_{\mathrm{ou}}$ = Oil uptake rate constant $\mathbf{K}_{\mathrm{ml}}$ = Moisture rate constant.

GJ \#2010= 'Georgia Jet clone \#2010'; WT='White Travis'; GJ='Georgia Jet'; GR= 'Ginseng Red'; B='Beauregard'

Table 2: Parameters of first-order kinetic model of oil uptake and moisture loss for different cultivars of sweet potato fried products.

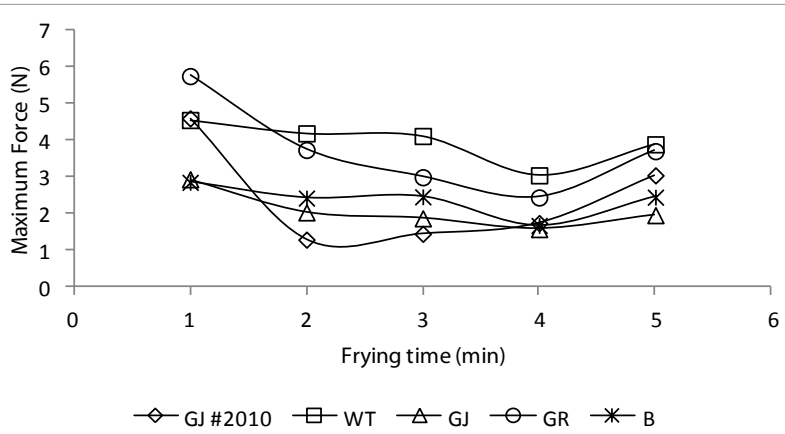

GJ \#2010= 'Georgia Jet clone \#2010'; WT='White Travis'; GJ='Georgia Jet'; $\mathrm{GR}=$ 'Ginseng Red'; B='Beauregard'

Figure 3: Maximum force of French fries produced with different sweet potato cultivars. 
elastic modulus $(4.16 \pm 1.58 \mathrm{~N} / \mathrm{mm})$ and maximum force $(3.97 \pm 1.17$ $\mathrm{N})$. Elastic modulus (Figure 4) is a function of the stiffness of fried product while maximum force achieved before fracture is function of hardness [30]. However, cultivar GR apparently produced crispy products. The sealing of the surface resulting in crispy product could explain the low oil saturation in its final products. Also, it had been reported that textural properties of fried products of starchy foods such as sweet potato are highly influenced by the gelatinization of the starch, level of sugar content and $\alpha$-amylase activity of the raw root cultivar, cell wall breakdown, dehydration and protein denature during frying $[31,32]$.

Colour analysis of the five cultivars is presented in Figure 5-7. All the cultivars had bright products $(\mathrm{L}>50)$. This observation is not surprising because sweet potato is low in reducing sugar content [33]. The result showed variation in browning among cultivars. Redness parameter was significantly highest in cultivar B $(20.57 \pm 0.93)$ followed by cultivar GR $(9.98 \pm 0.88)$ then lowest in GJ $(0.22 \pm 0.97)$ and GJ \#2010 (0.20 \pm 0.99$)$. The trend of redness parameter implies that all cultivar products tended toward browning with increased frying time. This indicates more maillard reaction with frying time which utilizes available reducing sugars in the sweet potato [9]. This finding is in agreement with the study of [31], which demonstrated the influence of variety and genetic makeup of sugar content in potato on browning during frying. The more redness value in cultivars B and GR in this study could therefore be attributed to high sugar content that reacts with amino acids in a non-enzymatic browning reaction during frying [34].

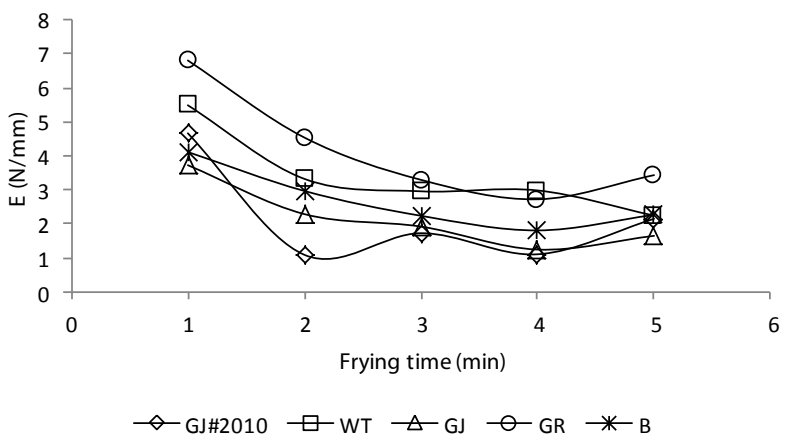

GJ \#2010= 'Georgia Jet clone \#2010'; WT='White Travis'; GJ='Georgia Jet'; $\mathrm{GR}=$ 'Ginseng Red'; B='Beauregard'

Figure 4: Elastic modulus of French fries produced with different sweet potato cultivars.

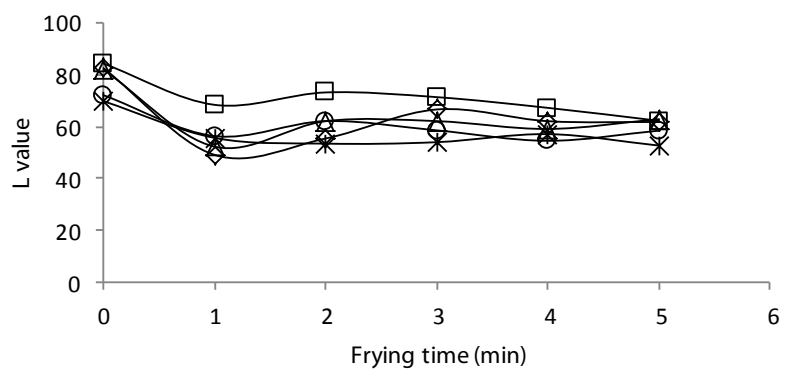

$\diamond \mathrm{GJ} \# 2010-\mathrm{GR} \rightarrow \mathrm{B}-\mathrm{B} \mathrm{WT} \triangle \mathrm{GJ}$

GJ \#2010= 'Georgia Jet clone \#2010'; WT='White Travis'; GJ='Georgia Jet'; GR= 'Ginseng Red'; B='Beauregard'

Figure 5: L-value for different sweet potato cultivars during deep frying.

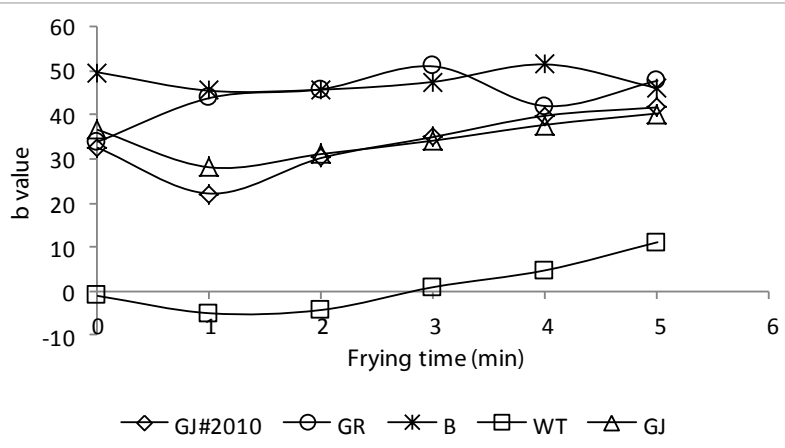

GJ \#2010= 'Georgia Jet clone \#2010'; WT='White Travis'; GJ='Georgia Jet' GR= 'Ginseng Red'; B='Beauregard'

Figure 6: b-value for different sweet potato cultivars during deep frying.

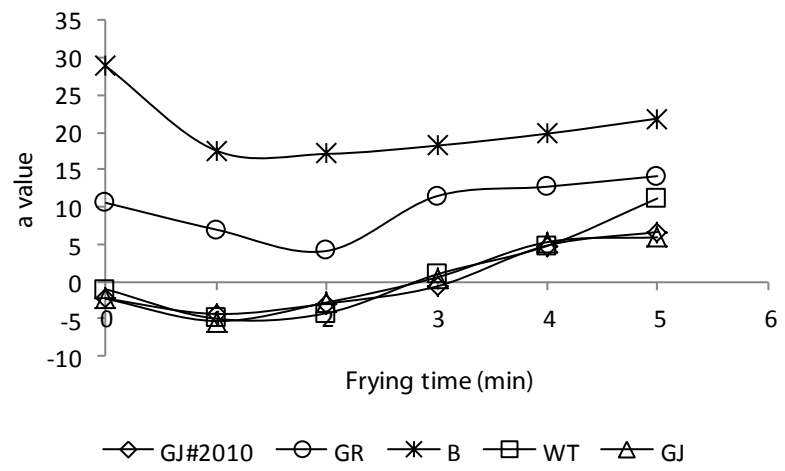

GJ \#2010= 'Georgia Jet clone \#2010'; WT='White Travis'; GJ='Georgia Jet'; $\mathrm{GR}=$ 'Ginseng Red'; B='Beauregard'

Figure 7: a-value for different sweet potato cultivars during deep frying.

Similarly, the yellowness parameter was significantly highest in cultivar B (47.71 \pm 0.66$)$ followed by cultivar GR $(44.11 \pm 1.32)$, while the other three cultivars (GJ \#2010, GJ, WT) had similar yellowness parameter $(\mathrm{P}>0.05)$. All cultivars tend toward yellowness with frying time which is desirable for fried products [35].

\section{Conclusion}

This study indicated that sweet potato products from different cultivars have different fried quality attributes. Cultivars GR and WT yielded fried products with lower oil content. Their products also tended to have desirable texture with bright colour. The other cultivars (B, GJ \#2010, and GJ) had high moisture content and consequently high oil absorption during frying. The difference in oil saturation between cultivar GR and the other cultivars is striking, defining their final oil intake. Cultivar GR resulted in lower oil content and crispy fried product

\section{References}

1. Wu X, Sun C, Yang L, Zeng G, Liu Z, et al. (2008) $\beta$-carotene content in sweet potato varieties from China and the effect of preparation on $\beta$-carotene retention in the Yanshu No. 5. Innovative Food Science \& Emerging Technologies 9 : 581-586.

2. Huang AS, Tanudjaja L, Lum D (1999) Content of alpha-, beta-carotene, and dietary fiber in 18 sweetpotato varieties grown in Hawaii. J Food Compost Anal 12: 147-151.

3. Tumuhimbise GA, Namutebi A, Muyonga JH (2009) Microstructure and in vitro beta carotene bioaccessibility of heat processed orange fleshed sweet potato. 
Citation: Odenigbo A, Rahimi J, Ngadi M, Wees D, Mustafa A, et al. (2012) Quality Changes in Different Cultivars of Sweet Potato During Deep-Fat Frying. J Food Process Technol 3:156. doi:10.4172/2157-7110.1000156

Plant Foods Hum Nutr 64: 312-318.

4. Turner T, Burri B (2001) Orange sweet potatoes are an excellent source of vitamin A. Agro Food Industry Hi-Tech 22: 14-16.

5. Farinu A, Baik OD (2007) Heat transfer coefficients during deep fat frying of sweetpotato: Effects of product size and oil temperature. Food Res Int 40: 989994.

6. Mellema M (2003) Mechanism and reduction of fat uptake in deep-fat fried foods. Trends Food Sci Technol 14: 364-373.

7. Nourian F, Ramaswamy HS, Kushalappa AC (2003) Kinetics of quality change associated with potatoes stored at different temperatures. LWT - Food Science and Technology 36: 49-65.

8. Bouchin P, Aguilera J, Pyle D (2003) Structure Oil-Absorption Relationships During Deep-Fat Frying. Journal of Food Science 68: 2711-2716.

9. Pedreschi F, Moyano P, Kaack K, Granby K (2005) Color changes and acrylamide formation in fried potato slices. Food Res Int 38: 1-9.

10. Kita A (2002) The influence of potato chemical composition on crisp texture Food Chem 76: 173-179.

11. Basuny AMM, Mostafa DMM, Shaker AM (2009) Relationship Between Chemical Composition and Sensory Evaluation of Potato Chips Made from Six Potato Varieties with Emphasis on the Quality of Fried Sunflower Oil. World Journal of Dairy \& Food Sciences 4: 193-200.

12. O'Connor CJ, Fisk KJ, Smith BG, Melton LD (2001) Fat uptake in French fries as affected by different potato varieties and processing. Journal of food science 66: 903-908.

13. Gazmuri A, Bouchon P (2009) Analysis of wheat gluten and starch matrices during deep-fat frying. Food Chem 115: 999-1005.

14. Debnath S, Bhat KK, Rastogi NK (2003) Effect of pre-drying on kinetics of moisture loss and oil uptake during deep fat frying of chickpea flour-based snack food. LWT - Food Science and Technology 36: 91-98.

15. Moyano PC, Pedreschi F (2006) Kinetics of oil uptake during frying of potato slices:: Effect of pre-treatments. LWT-Food Science and Technology 39: 285

16. Krokida MK, Oreopoulou V, Maroulis ZB, Marinos-Kouris D (2001) Effect of pre-drying on quality of french fries. J Food Eng 49: 347-354.

17. Nourian F, Ramaswamy HS (2003) Kinetics of quality change during cooking and frying of potatoes: Part I. Texture. J Food Process Eng 26: 377-394.

18. Abong GO, Ckoth MW, Imungi JK, Kabira JN (2011) Effect of Slice Thickness and Frying Temperature on Color, Texture and Sensory Properties of Crisps made from Four Kenyan Potato Cultivars. Am J Food Technol 6: 753-762.

19. Hagenimana V, Karuri EG, Oyunga MA (1998) Oil content in fried processed sweetpotato products. J Food Process Preserv 22: 123-137.
20. Abe S, Yamamuro Y, Tau K, Takenaga F, Suzuki K, et al. (2011) High-pressure and heat pretreatment effects on rehydration and quality of sweet potato. Am J Food Technol 6: 63-71.

21. La Bonte DR, Picha DH, Johnson HA (2000) Carbohydrate-related changes in sweetpotato storage roots during development. J Am Soc Hortic Sci 125 200-204.

22. Grube B (2007) Sweet potatoes in northern New England.

23. Sand Hill Preservation Center (2012) 1878, 230th Street Calamus, lowa 52729.

24. Taiwo KA, Baik OD (2007) Effects of pre-treatments on the shrinkage and textural properties of fried sweet potatoes. LWT-Food Science and Technology 40: 661-668.

25. AACC (1986) Moisture content. In Approved methods of the American Association of Chemists. St Paul, MN: AACC.

26. AOAC (1990) Official methods of analysis. Association of Official Analytica Chemists, Washington, DC

27. Kassama L, Ngadi M (2005) Pore development and moisture transfer in chicken meat during deep-fat frying. Drying Technology 23: 907-923.

28. Troncoso E, Pedreschi F (2009) Modeling water loss and oil uptake during vacuum frying of pre-treated potato slices. LWT-Food Science and Technology 42: $1164-1173$

29. Pedreschi F, Moyano $P$ (2005) Oil uptake and texture development in fried potato slices. J Food Eng 70: 557-563.

30. Miranda ML, Aguilera JM (2006) Structure and texture properties of fried potato products. Food Reviews International 22: 173-201.

31. Abong GO, Okoth MW, Karuri EG, Kabira JN, Mathooko FM (2009) Influence of potato cultivar and stage of maturity on oil content of French fries (chips) made from eight Kenyan potato cultivars. African Journal of Food, Agriculture, Nutrition and Development 9

32. Walter WM, Collins WW, Van-Den Truong, Fine TI (1997) Physical, compositional, and sensory properties of French fry-type products from five sweetpotato selections. J Agric Food Chem 45: 383-388.

33. Rose IM, Vasanthakaalam H (2011) Comparison of the Nutrient composition of four sweet potato varieties cultivated in Rwanda. Am J Food Nutr 1: 34-38.

34. Viklund GÅl, Olsson KM, Sjöholm IM, Skog KI (2010) Acrylamide in crisps: Effect of blanching studied on long-term stored potato clones. J Food Compost Anal 23: 194-198.

35. Krokida MK, Oreopoulou V, Maroulis ZB, Marinos-Kouris D (2001) Colou changes during deep fat frying. J Food Eng 48: 219-225. 